\title{
TUBER SIZE EFFECTS ON YIELD AND NUMBER OF POTATO MINITUBERS OF COMMERCIAL VARIETIES IN A GREENHOUSE PRODUCTION SYSTEM
}

\author{
Ercan OZKAYNAK* \\ *Yuksel Seed Company. Antalya, TURKEY \\ Kursunlu Mah. Madenler Sok. No:112/A, 07112, Antalya, TURKEY \\ Corresponding author: eozkaynak@yukseltohum.com
}

Received: 03.09.2020

\begin{abstract}
The aim of this study was to determine the effects of three different minituber (Mt) sizes (large, cutting and small) on the number and yield of minitubers (Mts) in 6 commercial potato varieties. The research was carried out according to the split plot design of greenhouse conditions in the 30x30cm plant density in 2017 and 2018 . From potato varieties, Soylu were given the highest values in large and small Mt sizes, the number of Mt per plant and per hectare. Mt weight per plant, average Mt weight and Mt yield per hectare Cevher variety showed better performance than other varieties. Approximately 48-50 \% of the Mts obtained in terms of Mt size were determined as Mts of $45-60 \mathrm{~mm}$. The size of the cutting Mt was given a higher yield per hectare and the number of Mts than the others. According to the results of the study, Mts of commercial varieties in greenhouse conditions were planted in $30 \times 30 \mathrm{~cm}$ plant density and $90 \%$ of them were planted directly in the field $(\geq 25 \mathrm{~mm}$ ), firstly. Approximately 700000 Mts can be produced from one hectare greenhouse in the greenhouse production system in narrow plant density.
\end{abstract}

Keywords: Conventional, mini tuber, Solanum tuberosum L., yield.

\section{INTRODUCTION}

Plant tissue culture techniques have been used effectively for different purposes in crop plants about 30 years. In vegetatively propagated plants, such as potato, it is possible to produce a great number of disease-free plants using micropropagation by tissue culture (Ozturk and Yildirim; 2014; Ozturk, 2017). These in vitro derived disease-free plants are used to produce minitubers (Mts), which are the initial source (classified as Super Elite seed in Turkey) of seed tuber multiplication program, under controlled greenhouse conditions (Ozturk and Yildirim, 2020). In vivo conditions; variety, plant age, plantation conditions, planting time, planting material, season and method, plant density, growing time, irrigation, fertilization- and harvest density and time factors affect production of Mts (Dimante and Gaile, 2015; Dimante et al., 2019; Farran and Mingo-Castel, 2006; Hossain et al., 2015; Ozkaynak and Samanci, 2005; Ozturk and Yildirim, 2010, 2011; Sadawarti et al., 2018; Sharma and Pandey, 2013; Veeken and Lommen, 2009).

Seed tuber size is one of the major factors affecting yield and quality in potato (Haverkort and Verhagen, 2008). Of these factors, seed tuber sizes is the most controllable one. A low variation in seed tuber size within the seed lot is desirable, especially in seed certification.
Different approaches have been evaluated in previous studies on tuber size distributions (Fulladolsa et al., 2018; Georgakis et al., 1997). The most common approach was a high number of tubers, or tuber yield obtained from a particular tuber size (Dimante et al., 2019). Park et al., (2009) have revealed that larger tubers give stronger plants and larger tubers while smaller ones produced smaller size tubers. Park et al., (2009) also stated that tuber size was a good guide for categorizing seed potato. Beukema and Zaag (1990) also determined that potato yield was subjective according to tuber size (Singh et al., 2019).

In Mt production, very few tubers can be harvested by planting at high density such as $100-200$ plant $\mathrm{m}^{-2}$ frequency. In potato, small (3-9 g) Mts are obtained in repetitive harvests and intensive labour is required. This type of production is not widely used in commercial production since small mini tubers have more weight loss compared to large tubers during storage, and they show poor performance after planting in field (Karafyllidis et al., 1997). In recent years, production of large Mts ( $\geq 10 \mathrm{~g})$ is preferred in commercial production (Veeken and Lommen, 2009). It has been reported that the knowledge about plant density mechanisms affecting the number and size of Mts in potato is limited and new researches should be needed (Veeken and, Lommen, 2009). 
Although large scale soilless Mt production systems are developed in some countries, conventional $\mathrm{Mt}$ production systems using solid substrates such as soil, peat etc., are still considered as the cheapest and practical way. In these systems, a large number of medium-sized Mts $(25-35 \mathrm{~mm})$ can be produced in a specific greenhouse area from in vitro plants (Dimante and Gaile, 2014). In research, there are two purposes to produce two rounds of Mts in greenhouse conditions. The first is to obtain a large number of clean and healthy seed tubers, the second is to obtain a large tuber that can be directly planted in the field. This research was conducted to determine the effects of Mts size and cutting on seed tuber yield and size distribution of six commercial potato varieties with highdensity planting under greenhouse conditions.

\section{MATERIALS AND METHODS}

\section{Plant Materials and Greenhouse Experiment}

In the research, different size Mts derived for 6 commercial potato varieties (Maraton (medium-early fresh market and French fry), Soylu (medium-late, high yield fresh market), Asya (medium-early, fresh market), Atabey (medium-late, fresh market), Cevher (crisp and French fry) and Demet (French fry) were used. Mts were produced using in vitro plants under greenhouse conditions in the spring season of 2017 and 2018. For multiplication of in vitro plants, single node explants obtained from in vitro stock plants of each potato variety were grown in petri dishes in MS medium for 2 weeks. Plants of 5-7 cm length were transferred to seedling nursery greenhouse by containing with $10 \%$ vermiculite, $25 \%$ perlite and $65 \%$ peat mixture in viols. After 20 days growing in seedling nursery, the plants were transplanted to soil with $60 \mathrm{~cm}$ row and $20 \mathrm{~cm}$ in-row spacing in greenhouse on 13 March 2017 and 15 March 2018. Standard management practices were followed during growing period, and Mts were harvested on 15 June 2017 and 20 June 2018.

After harvest, Mts of six varieties were divided into two categories: large $(25-35 \mathrm{~mm})$ and small $(<25 \mathrm{~mm}$, minimum $10 \mathrm{~mm}$ ) tubers, and some of large Mts were longitudinally cut to two before planting. The large whole Mt (25-35 mm), the cutting large Mt $(25-35 \mathrm{~mm})$ and the small whole Mt $(25 \mathrm{~mm})$ were used as a Mt size treatments. All size Mts of 6 potato varieties were planted in the greenhouse on September 14, 2017 and September 12,2018 with $30 \mathrm{~cm}$ row and in-row spacing. A Split-Plot Design with varieties as main plot and Mts as sub-plot was used with three replications in both years. Each sub plot consisted of four rows having $10 \mathrm{~m}$ long. All plots regularly irrigated using a drip irrigation system. A basal fertilizer of $15 \mathrm{~N}: 15 \mathrm{P}: 15 \mathrm{~K}$ balanced fertilizer was applied to experimental plots before planting in both years. Balanced fertilizer is given until flowering period during cultivation. Potato plants were grown after flowering, 1: 2: 1 (N: P: K) and tuber growth period stage 1: 1: 3 containing fertilization. Totally, $70 \mathrm{~kg} \mathrm{ha}^{-1} \mathrm{~N}, 40 \mathrm{~kg} \mathrm{ha}^{-1}$ $\mathrm{P}_{2} \mathrm{O}_{5}$ and $90 \mathrm{~kg} \mathrm{ha}^{-1} \mathrm{~K}_{2} \mathrm{O}$ were applied in all growing period. Mts harvests were performed on 27-28 December 2017 and 20-21 December 2018. After harvest, data were collected from 20 randomly selected plants in each plot.

\section{Weather conditions}

No artificial lighting or heating was carried out in the greenhouse during the research. Air temperature and daily hours of sunlight sum were presented the growing period. The plants were grown in an average temperature range of $18-31{ }^{\circ} \mathrm{C}$. The night temperature did not fall below $3{ }^{\circ} \mathrm{C}$. Humidity rate was at $60-80 \%$. In the greenhouse, the length of daily hours of sunlight sum varied between 8.5 11.4 hours at the planting and exiting stage (2017-2018), while it was approximately 6 hours in the harvesting period (Table 1).

Table 1. Climatological data of 2017 and 2018 potato growing season in Antalya Province

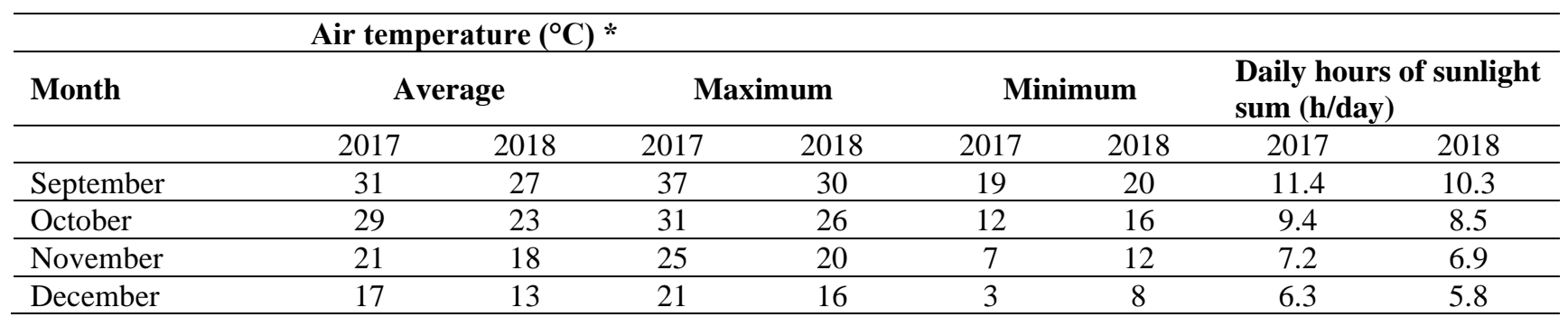

* Greenhouse temperature is approximately $5^{\circ} \mathrm{C}$ higher than air temperature

\section{Data collection and analysis}

After the harvest, the number of Mt per plant, the weight of Mt per plant, average Mt weight, the percentage of the Mt size, number of Mt number per hectare and Mt yield per hectare were determined. Hectare yield calculations were made according to the planting density of $30 \mathrm{~cm} \times 30 \mathrm{~cm}$ planting to $10000 \mathrm{~m}^{-2}$ and planted 110000 Mts ha- $^{1}$. All sizes $(10 \mathrm{~mm}$ to $50 \mathrm{~mm})$ weighed and calculated. The data were analysed by using MSTAT-C statistical program and mean values were separated by LSD test (Freed et al., 1989).

\section{RESULTS AND DISCUSSION}

Number of Mts per plant and per unit area with acceptable size are two main yield characteristics. It depends on a producer which of the two characters is accepted as the important one. In the event when Mts' grower is in vitro micropropagation producer at the same 
time, Mt number per area unit could become the most substantial character (Dimante and Gaile, 2015). In the study, large, cutting and small Mt characteristics of 6 varieties are given in Table 2. Significant differences were found between the studied varieties in terms of size of Mts. With regard to number of Mts per plant, the highest value was found in Soylu variety with 8.0 tuber. Other varieties gave similar values between 5.0-6.5. The lowest value of the tuber size was determined with a small Mt size as a 5.4. Ahloowalia (1994) reported that the number of tubers was the most important parameter for $\mathrm{Mt}$ production for seed. Struik (2007) abridged that the number of Mts per plant generally ranges from 2.0-5.0. Corrêa et al. (2008) reported that 7.0-8.31 and Roy et al. (1995) 11.1 Mt number per plant. Veeken and Lommen (2009) reported that the output of 5.4 Mt per plant. These differences could be clarified by several factors and various treatments such as varieties, different planting containers, growing mediums were used like this study.

Table 2. The number of Mt and Mt weight per plant, and average Mt weight produced by Mts of three tuber size in potato varieties average values of $2017-2018$

\begin{tabular}{|c|c|c|c|c|c|c|c|c|c|c|c|c|}
\hline \multirow[b]{2}{*}{$\begin{array}{l}\text { Variety } \\
\text { (V) }\end{array}$} & \multicolumn{4}{|c|}{$\begin{array}{c}\text { The Number of Mt per } \\
\text { Plant }\end{array}$} & \multicolumn{4}{|c|}{ The Weight of Mt per Plant (g) } & \multirow{2}{*}{$\begin{array}{l}\text { Average } \\
\text { (g) }\end{array}$} & \multirow{2}{*}{$\begin{array}{l}\text { Mt } \\
\text { C }\end{array}$} & \multirow{2}{*}{$\begin{array}{c}\text { Weight } \\
\mathrm{S}\end{array}$} & \multirow[b]{2}{*}{ Mean } \\
\hline & $\mathbf{L}$ & $\mathbf{C}$ & $\mathbf{S}$ & Mean & $\mathbf{L}$ & $\mathbf{C}$ & $\mathbf{S}$ & Mean & & & & \\
\hline Maraton & 5.8 & 8.0 & 5.8 & 6.5 & 330 & 440 & 348 & 373 & 57 & 55 & 60 & 57 \\
\hline Soylu & 7.8 & 10.6 & 5.6 & 8.0 & 388 & 496 & 264 & 383 & 50 & 47 & 47 & 48 \\
\hline Asya & 6.8 & 5.4 & 5.8 & 6.0 & 424 & 340 & 392 & 385 & 62 & 63 & 67 & 64 \\
\hline Atabey & 5.6 & 4.6 & 4.6 & 5.0 & 424 & 332 & 260 & 339 & 76 & 72 & 57 & 68 \\
\hline Cevher & 5.6 & 6.4 & 5.0 & 5.7 & 488 & 500 & 310 & 433 & 87 & 78 & 67 & 77 \\
\hline Demet & 5.6 & 6.0 & 5.4 & 5.7 & 344 & 384 & 392 & 373 & 61 & 64 & 73 & 66 \\
\hline Mean & 6.2 & 6.8 & 5.4 & 6.1 & 400 & 415 & 328 & 381 & 66 & 63 & 62 & 63 \\
\hline $\operatorname{LSD}(0.05)$ & & & & & \multicolumn{4}{|c|}{$\operatorname{LSD}(0.05)$} & \multicolumn{4}{|c|}{$\operatorname{LSD}(0.05)$} \\
\hline $\mathrm{V}$ & 0.85 & & & & $\mathrm{~V}$ & 20.9 & & & $\mathrm{~V}$ & 6.9 & & \\
\hline MS & 1.40 & & & & MS & 29.7 & & & MS & n.s. & & \\
\hline VxMS & 2.09 & & & & VxMS & 25.6 & & & VxMS & n.s. & & \\
\hline
\end{tabular}

Mt: Mini tuber, MS: Mini tuber size, L: Large Mt, C: Cutting Mt, S: Small Mt, Variety: V, Mt Size: MS, n.s.: nonsignificant

There were significantly important differences between varieties in the weight of MT per plant. The highest value in terms of Mt weight per plant was obtained in Cevher with $433 \mathrm{~g}$. The average weight of Mt per plant was found to be $381 \mathrm{~g}$. The small Mt size gave the lowest value, whereas the cutting Mt size gave the highest values. The average Mt weight was found to be the highest in the large tuber size. Significant differences were obtained between the varieties in terms of the average Mt weight. The average Mt weight ranged from 48 to $77 \mathrm{~g}$ in the potato varieties. Dimante and Gaile (2015) investigated the effect of different planting densities $\left(63,95\right.$ and 142 plants per $\left.\mathrm{m}^{-2}\right)$ on Mt production in greenhouse conditions. They were found that Mts per plant 2.7 to 4.3 and average weight of Mts from $12.11 \mathrm{~g}$ to 20.26 g. Mt number and weight were obtained lower than our results, because of higher plant density.

The analyses of variance for the percentage of MT size are represent in Table 3. There were statistically significant differences among the Mt sizes. Mahmoudpour (2014) was investigated different Mt size (1 g, 1-5 g, 5-10 $\mathrm{g},>10 \mathrm{~g}$ ) effects on Agria variety in pots. The results showed that Mt weight per plant and the yield per area unit increased following the increase in Mt sizes. The highest average number of Mts was achieved from 5-10 g Mt sizes. Dimante and Gaile (2015) reported that the production of Mts in low plant density (rare plantings) is a good practice for the production of a higher number of Mts at a commercial level (>9 mm). In this way it is also stated that a higher average tuber weight is obtained. By reducing the plant density from 145.8 to 25 in the unit area, two times more harvestable tubers per plant were obtained, while at the same time the labour-time and toolequipment requirement in vitro production decreased by half. However, the reduction of the plant density from 145.8 to 25 reduced the number of Mts per $\mathrm{m}^{-2}$ to a ratio of 3 to 1 . Similarly, in our study $90 \%$ of Mt was obtained bigger than $>25 \mathrm{~mm}$ at $30 \times 30 \mathrm{~cm}$ plant density. Hossain et al., (2015) were investigated six different Mt size $(<5 \mathrm{~mm}$, 5-10 mm, 10-15 mm, 15-20 mm, 20-25 mm, > $25 \mathrm{~mm}$ ) and four planting distance $(10,15,20,25 \mathrm{~cm})$ and their effects on growth and seed yield in Diamant variety. The largest Mts (> $25 \mathrm{~mm}$ ) gave the highest number of tubers per plant (18.7) when planted in $25 \mathrm{~cm}$ plant density. The highest number of tubers $\mathrm{m}^{2}$ (306.7) were obtained in 10 $\mathrm{cm}$ plant density in the largest Mts (> $25 \mathrm{~mm}$ ). As a results of the Hossain et al. (2015), similar to our results, larger size of Mt produced more and more seed tuber number with increased yield when it was planted in greater planting distance.

Significant differences were found between the studied varieties in terms of number and yield per hectare Mts. For the number of Mts per hectare, the highest values of varieties were obtained in Soylu and Maraton. Among the Mt sizes, the highest value was about 750000 in cutting Mt size (Table 4). In greenhouse conditions, 650000 Mts can be obtained on average from 1 hectare with a distance of $30 \times 30 \mathrm{~cm}$. The highest MT yield for hectare was 
obtained in variety Cevher, followed by Asya and Soylu. According to the other applications Mt yield per hectare was obtained higher in the size of the cutting tuber size. Many plant husbandry techniques have been used to modify the Mt yield parameters. These techniques were included planting density, development medium, fertilization, growing containers, pots and others. In many cases all these applications and factors may interact; therefore, when one of them is changed, other yield parameters can be changed (Dimante and Gaile, 2014; Sharma and Pandey, 2013). Santos and Rodriguez (2008) were evaluated the yield of Mts by planting the germinated microtubers in 20,25,30,35 and $40 \mathrm{~cm}$ rows in open field. Mt weight per plant was $195 \mathrm{~g}$ and 269 plant $^{-1}$ at $20 \mathrm{~cm}$ and $40 \mathrm{~cm}$, respectively. The number of Mts per hectare was 425000 in $20 \mathrm{~cm}$ and 119000 in 40 $\mathrm{cm}$. The number of Mts per plant was highest with an average of $6.5,20$ and $25 \mathrm{~cm}$ in distances. The most suitable row line distances were recommended as 20 and $25 \mathrm{~cm}$ intervals. In our study, Mt weight per plant and number of Mts per hectare were obtained higher comparing to Santos and Rodriguez (2008). For the values of Mt number per plant were similar to Santos and Rodriguez (2008).

Table 3. The percentage of Mt size produced by Mts of three tuber size in potato varieties average values of 2017-2018

\begin{tabular}{|c|c|c|c|c|c|c|c|c|c|}
\hline \multirow{3}{*}{ Variety } & \multicolumn{9}{|c|}{ The Percentage of The Mt Size (\%) } \\
\hline & Large & & & Cutting & & & Small & & \\
\hline & $\begin{array}{l}\text { 45-50 } \\
\mathrm{mm}\end{array}$ & *35 mm & $<25 \mathrm{~mm}$ & $\begin{array}{l}\text { 45-50 } \\
\mathrm{mm}\end{array}$ & *35 mm & $<25 \mathrm{~mm}$ & $\begin{array}{l}45-50 \\
\mathrm{~mm}\end{array}$ & $\begin{array}{l}* 35 \\
\text { mm }\end{array}$ & $\begin{array}{l}<25 \\
\mathrm{~mm}\end{array}$ \\
\hline Maraton & 48 & 45 & 7 & 44 & 42 & 14 & 50 & 42 & 8 \\
\hline Soylu & 33 & 52 & 15 & 45 & 43 & 12 & 36 & 50 & 14 \\
\hline Asya & 53 & 45 & 5 & 52 & 39 & 9 & 49 & 46 & 5 \\
\hline Atabey & 54 & 37 & 9 & 61 & 35 & 4 & 43 & 44 & 13 \\
\hline Cevher & 62 & 35 & 3 & 49 & 46 & 5 & 60 & 29 & 11 \\
\hline Demet & 52 & 40 & 8 & 47 & 48 & 5 & 52 & 44 & 4 \\
\hline Mean & 50.33 & 42.33 & 7.83 & 49.67 & 42.17 & 8.17 & 48.33 & 42.50 & 9.17 \\
\hline${ }^{\mathrm{a}} \operatorname{LSD}(0.05)$ & & $\mathrm{V}: 6.5$ & & MS: 8.4 & & VxMS: 1 & & & \\
\hline
\end{tabular}

Table 4. The number of Mt and Mt yield per hectare produced by Mts of three tuber size in potato varieties average values of 2017 2018

\begin{tabular}{|c|c|c|c|c|c|c|c|c|}
\hline \multirow[b]{2}{*}{ Variety } & \multicolumn{4}{|c|}{ Number of Mts ha ${ }^{-1}$} & \multicolumn{4}{|c|}{ Mt Yield ha-1 (Kg) } \\
\hline & Large & Cutting & Small & Mean & Large & Cutting & Small & Mean \\
\hline Maraton & 638000 & 880000 & 638000 & 718667 & 36300 & 48400 & 38260 & 40987 \\
\hline Soylu & 858000 & 1166000 & 616000 & 880000 & 42680 & 54560 & 29040 & 42093 \\
\hline Asya & 748000 & 594000 & 638000 & 660000 & 46640 & 37400 & 43120 & 42387 \\
\hline Atabey & 616000 & 506000 & 506000 & 542667 & 46640 & 36520 & 28600 & 37253 \\
\hline Cevher & 616000 & 704000 & 550000 & 623333 & 53680 & 55000 & 34100 & 47593 \\
\hline Demet & 616000 & 660000 & 594000 & 623333 & 37840 & 42240 & 43120 & 41067 \\
\hline Mean & 682000 & 751667 & 590333 & 674667 & 43963 & 45687 & 36040 & 41897 \\
\hline $\operatorname{LSD}(0.05)$ & & & & & $\mathrm{LSD}(0$ & & & \\
\hline $\mathrm{V}$ & 6358.3 & & & & $\mathrm{~V}$ & 2468.5 & & \\
\hline MS & 6862.4 & & & & MS & 2983.2 & & \\
\hline VxMS & 7210.7 & & & & VxMS & 3306.6 & & \\
\hline
\end{tabular}

Large: Large Mt, Cutting: Cutting Mt, Small: Small Mt, Variety: V, Mt Size: MS, n.s.: nonsignificant

Veeken and Lommen (2009) were investigated the effects of different plant densities on the yield and number of Mts in commercial production conditions. In the study, 3 different plant density applications $(25,62.5$ and 145.8 plant $\mathrm{m}^{-2}$ ) were investigated. Low plant density were increased the number of tubers per plant in all Mt sizes. Although a smaller number of Mts than $\mathrm{m}^{-2}$ was obtained in low plant density, higher weight were found per plant. Thus, the total tuber weight obtained from $\mathrm{m}^{-2}$ were increased. Similarly, in this study, although less tubers per plant were obtained in rarely planting $(30 \times 30 \mathrm{~cm})$, more mini tubers that could be used in direct seed production were obtained. Plant growth and development is better rare plantings because have less competition between plants in terms of light, water and nutrients. Sadawarti et al., (2018) were tested for seed production systems in vitro plants, microtubers and Mts performance of seven varieties during 10 years. They were reported that there was different performance among different potato varieties for average tuber weight, tuber number and weight per plant, $<3 \mathrm{~g}$ tuber percent and tuber yield per $\mathrm{m}^{-}$ 2. At the end of the research, they were stated that compare to in vitro plant and microtuber systems $\mathrm{Mt}$ production system was the best one for tuber yield characteristic. 
In accordance with the findings of the research, it was stated that the production of Mts is significantly dependent on genotype and the differences in the production capacity of Mts of varieties (Mohamed et al., 2018; Sadawarti et al., 2018; Sharma et al., 2013; Venkatasalam et al., 2011). Among the high and lowyielding varieties, it is reported that there might be differences of up to 10 times in terms of $\mathrm{Mt}$ yield (Ahloowalia, 1994). Among the varieties of potato, it has been reported that there may be significant differences in the in vitro plants development in the greenhouse, the area occupied by plants, the number of Mts and yield (Kumar et al., 2011). Similar to Ahloowalia (1994), Kumar et al. (2011), Venkatasalam et al. (2011), and Sharma et al. (2013)s' findings, Soylu, Maraton and Asya varieties have high yield capacity commercial potato varieties. The Mts of these varieties also gave a high level of number of Mt per plant and the number of Mt per hectare. The varietal and genotypic differences in terms of Mt number per plant have been approved by other researches (Ahloowalia, 1994; Dimante and Gaile, 2014; Dimante and Gaile, 2018; Dimante et al., 2019; Mallick et al., 2017; Mohamed et al., 2018; Otroshy, 2006; Ozturk and Yildirim, 2011; Struik, 2007; Zimba et al., 2014).

\section{CONCLUSION}

The size of the Mt used in the production of seed potato is very important in terms of yield and quality of the tuber obtained from the unit area. If small Mts are to be used in production, some problems may arise due to poor growth and development in plants and in the first development periods as the Mt size is small in field conditions. This study was conducted in order to produce the maximum number of Mts from the unit area. 90-92\% of Mts were obtained bigger than $35 \mathrm{~mm}$ in the varieties and applications. Mts bigger than $35 \mathrm{~mm}$ are large enough to be planted directly in the field. 111000 plants or Mts can be planted at a distance of $30 \times 30 \mathrm{~cm}$ and over a hectare of a greenhouse area. On average $111000 \mathrm{Mt}$ commercial potato varieties, approximately 620000650000 large and high quality Mts can be obtained. In greenhouse conditions, Mts obtained from in vitro plants can be germinated and reproduced second time in greenhouse conditions. Therefore, in the greenhouse conditions, it is produced in clean and healthy environment and super elite stage Mts can be produced. The obtained Mts meet the necessary requirements for the elite, original, basic and certified stages of seed potato production in the later stages. In the research, it was concluded that Mts grown from in vitro plants in commercial potato varieties can be planted with $30 \times 30 \mathrm{~cm}$ row intervals in greenhouse conditions and a quality and healthy minituber can be produced in a size that can be planted directly on the field at a rate of over $90 \%$, firstly.

\section{LITERATURE CITED}

Ahloowalia, B.S. 1994. Production and performance of potato mini-tubers. Euphytica 75(3): 163-172.

Beukema, H.P. and V.D. Zaag. 1990. Introduction to Potato Production. Wegeningen. Netherlands. 207.
Corrêa, R.M., J.E.B.P. Pinto, V. Pinto, É.S. Faquin, A.B. Reis and W.E. Monteiro Dyer. 2008. A comparison of potato seed tuber yields in beds, pots and hydroponic systems. Scientia Horticulturae 116(1): 17-20.

Dimante, I. and Z. Gaile. 2014. Potato minitubers technology its development and diversity. Research for Rural Development 1: 69-76.

Dimante, I. and Z. Gaile. 2015. The effect of planting density on potato (Solanum tuberosum L.) minituber number, weight and multiplication rate. Research for Rural Development 1: 27-33.

Dimante, I. and Z. Gaile. 2018. Assessment of potato plant development from Minitubers. Agronomy Research 16(4): 1630-1641.

Dimante,I., I. Mežaka and Z. Gaile. 2019. The effect of minituber weight on their field performance under a Northern European environment. Agronomy Research 17(2): 396-407.

Farran, I. and A.M. Mingo Castel. 2006. Potato minituber production using aeroponics: effect of plant density and harvesting intervals. American Journal of Potato Research 83: 47-53.

Freed, R., S.P. Einensmith, S. Guetz, D. Reicosky, V.W. Smail and P. Wolberg. 1989. User's Guide to MSTAT-C Analysis of Agronomic Research Experiments. Michigan State University, USA.

Fulladolsa, A.C., K.E. LaPlant, R.L. Groves and A.O. Charkowski. 2018. Potato plants grown from minitubers are delayed in maturity and lower in yield, but are not at a higher risk of potato virus $\mathrm{Y}$ infection than plants grown from conventional seed. American Journal of Potato Research 95(1): 45-53.

Georgakis, D.N., D.I. Karafyllidis, N.I. Stavropoulos, E.X. Nianiou and I.A. Vezyroglou. 1997. Effect of planting density and size of potato seed-minitubers on the size of the produced potato seed tubers. Acta Horticulturae 462: 935942.

Haverkort, A.J. and A. Verhagen. 2008. Climate change and its repercussions for the potato supply chain. Potato Research 51(3-4): 223-237.

Hossain, A, A. Mahmud, A. Mamun, Md. Shamimuzzaman and M. Rahman. 2015. Optimization of minituber size and planting distance for the breeder seed production of potato. American Journal of Agriculture and Forestry 3(2): 58-64.

Karafyllidis, D.I., D.N. Georgakis, N.I. Stavropoulos, I.A. Vezyroglou and E.X. Nianiou. 1997. Effect of planting density and size of potato minitubers on their yielding capacity. Acta Horticulturae 462: 943-949.

Kumar, D., V. Singh and B.P. Singh. 2011. Growth and yield of potato plants developed from in vitro plantlets in nethouse. Potato Journal 38(2): 143-148.

Mahmoudpour, A. 2014. Effects of different sizes of Mini-tuber on yield and yield components of potato variety Agria. International Journal of Advanced Biological and Biomedical Research 2(4): 1099-1104.

Mallick, S.R., M.A. Hossain, M.M. Rahman, R. Sarker and S.A. Jui. 2017. Minituber Yield Potentials of Potato Varieties of Bangladesh. International Journal of Agricultural Papers 2 (2): $22-30$

Mohamed, F.H., G.F. Omar, K.E. El-Hamed and B. El-Safty. 2018. Influence of Plant Density and Genotype on Potato Minituber Production from Microshoots and Microtubers. CATRINA. 17 (1): 77-84.

Otroshy, M. 2006. Utilization of tissue culture techniques in a seed potato tuber production scheme. $\mathrm{PhD}$ Thesis, Wageningen University Wageningen, The Netherlands, 264 p. 
Ozkaynak, E. and B. Samanci. 2005. Yield and yield components of greenhouse, field and seed bed grown potato (Solanum tuberosum L.) plantlets. Journal of Akdeniz University Faculty of Agriculture 18(1): 125-29.

Ozturk, G. and Z. Yildirim. 2010. A comparoson of Field Performances of Minitubers and Microtubers used in seed potato Production. Turkish Journal of Field Crops 15: 141147.

Ozturk, G. and Z. Yildirim. 2011. Uniformity of Potato Minitubers Derived From Meristem Cultures of Nuclear Seed Stocks. Turkish Journal of Field Crops 16: 149-152.

Ozturk, G. and Z. Yildirim. 2014. Comparison of old and new clones of potato nuclear seed stocks for tuber uniformity in the greenhouse. Turkish Journal of Field Crops 19: 90-95.

Ozturk, G. 2017. Determination of the Morphological and Yield Characteristics of Old and New Meristem Stocks Used in Basic Seed Production in Potatoes (Solanum tuberosum L.). Journal of Agriculture Faculty of Ege University 54: 293-300.

Ozturk, G. and Z. Yildirim. 2020. Tuber characteristics of disease free meristem clones of some potato genotypes. Turkish Journal of Field Crops 25: 174-180.

Park, S.W., J.H. Jeon, H.S. Kim, S.J. Hong and C.A.H. Joung. 2009. The effect of size and quality of potato microtubers on quality of seed potatoes in cultivar 'Superior'. Scientia Horticulture 120(1): 127-129.

Roy, R.D., V. Souza Machado, S.M.M. Alam and A Ali. 1995. Greenhouse production of potato (Solanum tuberosum L. cv. Desire) seed tubers using in vitro plantlets and rooted cuttings in large propagation beds. Potato Research 38(1): 61-68.

Sadawarti, M.J., R.K. Samadhiya, V. Kumar, S.P. Singh Roy, E.P., Venkatasalam, T., Buckseth, R.K., Singh, K.K., Pandey, S.K. Chakrabarti. 2018. Hi-tech planting materials performance under in vivo conditions for potato breeder seed production. International Journal of Chemical Studies 6(3):817-822.

Santos, B.M. and P.R. Rodriguez. 2008. Optimum in-row distances for potato minituber production. HortTechnology. 18(3): 403-406.

Sharma, A.K. and K.K. Pandey. 2013. Potato mini-tuber production through direct transplanting of in vitro plantlets in green or screen houses. Potato Journal 40(2): 95-103.

Sharma, A.K., E.P. Venkatasalam and V. Kumar. 2013. Potato mini-tuber production during main and off crop seasons in high hills of north-western Himalaya. Potato Journal 40(1): 29-37.

Singh, P., J. Singh, A. Mirza. 2019. Standardization of fundamental components in aeroponics for minituber seed potato production : A Review. Plant Archives 19(2): 19681972.

Struik, P.C. 2007. The canon of potato science: minitubers. Potato Research 50(3-4): 305-308.

Veeken, A.J.H. and W.J.M. Lommen. 2009. How planting density affects number and yield of potato minitubers in a commercial glasshouse production system. Potato Research 52: 105-119.

Venkatasalam, E.P., J. Latawa, S. Sharma, S. Sharma, A.K. Sharma, S. Sharma, R. Patial and S. Singh. 2011. In vitro and in vivo performance of potato cultivars for different seed production systems. Potato Journal 38(2): 149-154.

Zimba, C., J.P. Njoloma, J.A. Nyaika, W.F. Mwase, M.F. Maliro, J.M. Bokosi and M.B. Kwapata. 2014. Minituber production potential of selected Potato (Solanum tuberosum L.) genotypes in different propagation media. African Journal of Biotechnology 13(48): 4430-4437. 